\title{
Development of Entrepreneurship Learning Media Based on Problem-Based Learning (PBL)
}

\author{
Dita Eka Pratiwi Sirait ${ }^{1 *}$, Charles Fransiscus Ambarita ${ }^{2}$, Rotua T. S. \\ Simanullang ${ }^{3}$
}

\author{
${ }^{1}$ Department of Business Education, Faculty of Economics, Universitas Negeri Medan, Indonesia \\ ${ }^{2}$ Department of Economic Education, Faculty of Economics, Universitas Negeri Medan, Indonesia \\ ${ }^{3}$ Department of Office Administration, Faculty of Economics, Universitas Negeri Medan, Indonesia \\ *Corresponding author. Email: ditaekapertiwi@unimed.ac.id
}

\begin{abstract}
The Pandemic of Covid 19 already caused major changes, include learning system in Education Sector. Online Learning have been used during the pandemic situation. Many problems have occurred related to the development interesting learning media to improve students understanding of the subject matter. Entrepreneurship is the one of subject which have to be taken by all students in Faculty of Economic UNIMED. The learning media developed is in the form of learning videos based on PBL Method. The Content and Media of learning Videos in this research have been validated by content expert and media aspect on categorized feasible to use.
\end{abstract}

Keywords: Learning media, learning video, PBL

\section{INTRODUCTION}

The world of education continues to develop, both in terms of learning content (materials) and learning media. The condition of the COVID-19 pandemic that occurred caused a huge impact on various sectors, one of which was the education sector. During the pandemic, all educational institutions must adopt online learning, where previously most educational institutions only used offline learning. This causes the online learning process to be an absolute must and must be well prepared so that teaching and learning activities can run smoothly. The online learning process requires learning media that can generate student interest in understanding the material being taught, one of which is by designing interesting learning media such as learning video. Learning media is a tool in the learning process both inside and outside the classroom, further explained that learning media is a component of learning resources or physical vehicles that contain instructional materials in the student environment that can stimulate students to learn [1]. One of the learning media that can be used is by using audio-visual media, such as video. Video is an audio-visual medium that displays motion [2]. In other literature we can find that instructional video media is media that presents audio and visuals that contain good learning messages that contain concepts, principles, procedures, theory of application of knowledge to help understanding of a learning material. Video is a visible and heard learning material (audio visual) that can be used to convey messages / subject matter. It is said to be seen to hear because the elements of hearing (audio) and elements of visual/video (appearing) can be presented simultaneously [3]. Based on previous research, the majority of students feel less interested in carry out virtual learning. However, the platforms that are often used are via WhatsApp Groups. Virtual learning leads to a lack of self-confidence students in opinion. Compared to non-virtual learning, virtual learning has an unstructured and coordinated learning schedule [4].

Entrepreneurship is the one subject that must be taken by all students in every study program in universities, including the UNIMED Faculty of Economics. This course teaches about entrepreneurship. Students are expected to be able to make a business plan from the marketing, technical, financial and human resource aspects. Various 
sources of learning for this course can be accessed by students, both from the internet and from printed books. However, these sources are not based on problem-based learning (PBL) which can train students to think critically.

The Problem Based Learning (PBL) learning model is a learning model based on many problems that require authentic investigations, namely investigations that require real solutions to real problems [5].

Research found that the application of the Problem Based Learning model to improve student learning processes and outcomes was quite effective, as seen from the increase in the percentage of student activity in each cycle [6]. This increase can be achieved because of students' enthusiasm for learning and the effective role of teachers in problem solving guidance. The Problem Based Learning model used with group work methods and selfdiscovery makes students find the concept of problem solving, if there is something they don't understand, students have started to dare to ask the teacher, so they can better master the material being taught.

\section{METHOD}

This research is a research and development $(\mathrm{R} \& \mathrm{D})$ research, which is a type of research that produces a product instead of testing a theory. Research and development is a process used to develop and validate educational products, test the effectiveness of these products, and can be accounted for [7]. This research will produce learning videos of entrepreneurship subject.

The model used in this study is ADDIE (ADDIE models). ADDIE model was popularized by Robert Maribe in 2009. ADDIE stands for (AnalysisDesign-Develop-Implement-Evaluate). The ADDIE model has a single unit that is integrated with one another each other. One of the functions of the ADDIE model is a model that can be used as a guideline that is dynamic and effective [8].

The research data were analyzed to determine the feasibility (validity) of Enterepreneurship Learning Media based on PBL Method. The validity of the learning media can be seen from the validation chart filled by the expert and the results of questions and answers during the validation process.

\section{RESULTS}

\subsection{Analysis Stage}

This study aims to develop a problem-based learning video using the ADDIE model. At the analysis stage, researchers conducted a needs analysis of the need for learning media to be developed. Based on the analysis at this stage, it was found that the problems faced by students were: students had difficulties when doing assignments or questions that required critical thinking skills. Students are only able to understand by explaining a concept in the learning material. However, if asked to analyse a problem related to the material, students have not been able to answer well.

\subsection{Design Stage}

In the Design Phase, the researcher designs learning media in the form of problem-based learning-based learning videos, where the video content begins with an example of problems related to the material to be discussed.

\subsection{Development Stage}

In this stage, this learning video was validated by two experts, namely: material expert and media expert. The material expert validates 3 components, namely: the content feasibility component, the presentation component and the linguistic component. The following are the results of the validation of the material on the learning media developed in this study, which are:

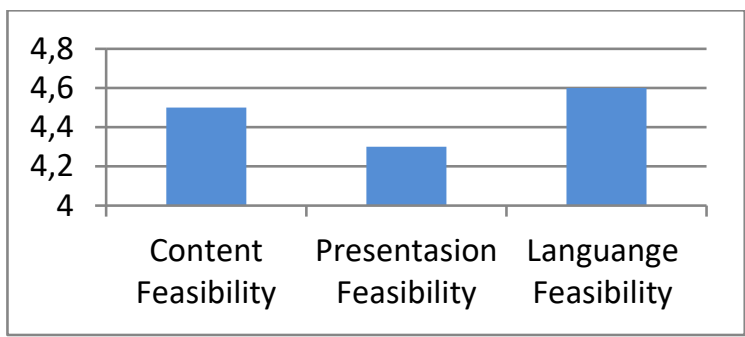

Figure 1. The Result of Score Average of Content (material) validation

Based on the figure above, it can be seen that the content feasibility component has an average score of 4.5 , which means that the content component is feasible to use. The average result of the validation score for the feasibility of the display is 4.3 , thus the display of the material is declared suitable for use. Then the average score for the validation of language feasibility is also declared feasible with a value of 4.6. Content feasibility consists of 5 assessment items, the presentation component consists of 10 
assessment items, and the linguistic component consists of 11 assessment items.

The next step is to validate the developed media which is carried out by the media validator. Aspects that are assessed on this media include: Visual aspects of media, Audio aspects of Media and language aspects. The results of the media expert's assessment of the three aspects are as follows:

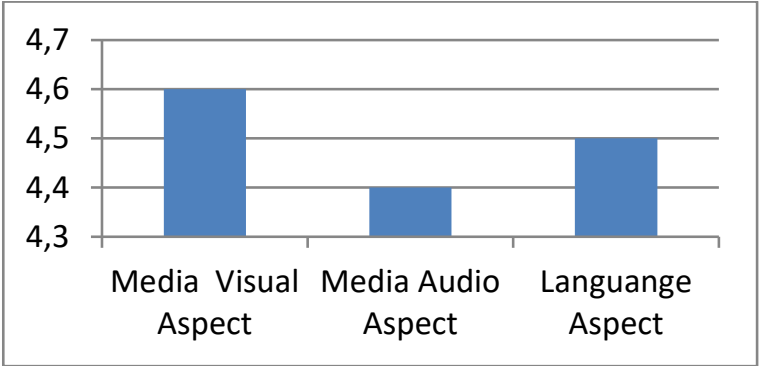

Figure 2. The Result of Score Average of Content Media validation

Based on the table above, it can be seen that the visual media aspect has an average score of 4.6, which means that the visual aspect of the media is feasible to use. The average validation score for the audio media aspect is 4.4 , thus the display of the audio media aspect is declared suitable for use. Then the average score for the validation of language eligibility is also declared feasible with a value of 4.5. The visual aspect of the media consists of 5 assessment items, the presentation component consists of 5 assessment items, and the linguistic component consists of 4 assessment items.

\section{DISCUSSION}

Based on the results and discussion of research, the development of entrepreneurship learning media based PBL still has shortcomings and needs to be improved, for example in terms of animation creativity which is more interesting to make it easier for students to absorb the content of the material taught in the video. For this reason, researchers suggest that further research needs to be carried out experimental research to test the effectiveness of learning videos using the experimental class and the control class.

\section{CONCLUSION}

This research and development aims to produce an entrepreneurship Learning Media based PBL developed through the ADDIE model (ADDIE model). The developed learning video have been validated by Content (Material) Expert and Media Expert. The Result of validation showed that content and media of learning video have been categorized as feasible to use.

\section{REFERENCES}

[1] Arsyad. Azhar, Media Pembelajaran, Jakarta: PT. Raja Grafindo Persada. 2011.

[2] Sadiman, Arif S, dkk, Media Pendidikan, Jakarta: PT. Raja Grafindo Persada. 2008.

[3] Cheppy, Riyana , Pedoman Pengembangan Media Video, Jakarta: P3AI UPI. 2007.

[4] Andarukmi,Nur Fitri, dkk. Efektivitas Pembelajaran Virtual Bagi Mahasiswa Geografi Universitas Negeri Malang, Jurnal Pendidikan Geografi Undiksha, Vol.9 No. 1 ISSN 2614591X, E ISSN: 2614- 1098, 2021

[5] Kusumawati, Ratna. et al, Keefektifan Penerapan Model Problem Based Learning (PBL) dan Model Learning Cycle 7E (LC7E) serta Integrasinya Terhadap Hasil Belajar Ditinjau dari Kemampuan Regulasi Diri dan Kreativitas Siswa. Bioedukasi Vol.7, No.1 ISSN 1693-2654, 2014.

[6] Trianto, Model Pembelajaran Terpadu. Jakarta: Bumi Aksara, 2010

[7] Sugiyono, Metode Penelitian Kuantitatif, Kualitatif, dan R\&D. Bandung: Alfabeta. 2013 